KATRINA Bell McDonald Johns Hopkins University

Elizabeth M. Armstrong University of Michigan*

\title{
De-Romanticizing Black Intergenerational Support: The Questionable Expectations of Welfare Reform
}

Past research suggests that despite the substantial strengths of Black kin networks, they are not always up to the task of supporting young mothers. This study is an analysis of potential barriers to women-centered kin support for present-day urban Black teen mothers and possible implications for kin support mandates specified in the 1996 federal welfare reforms. In-depth interviews with African American midlife women, who themselves were teen mothers, shed light on their attitudes and perceptions about Black kinship systems and teen childbearing. Study results suggest that these women perceive governmental intervention, agecondensation among urban Black families, and urban "underclass" culture to have undermined traditional Black intergenerational support.

Prior research suggests that young African American mothers are very likely to be embedded within a network of elder women kin. These kin, often thought of as midlife Black "activist mothers" (Naples, 1992) or community "othermothers" (James, 1993) are particularly concerned with

Department of Sociology, Johns Hopkins University, 3400 North Charles Street, 540 Mergenthaler Hall, Baltimore, MD 21218 (mcdon@jhu.edu).

*University of Michigan, Department of Health Management and Policy, 109 S. Observatory, SPH-I, Room M2224 Ann Arbor, MI 48109-2029.

Key Words: African Americans, intergenerational support, teen childbearing, welfare reform. supporting socially and economically disadvantaged, unmarried young mothers and their offspring (Ball, Warheit, Vandiver, \& Holzer, 1980; Collins, 1991; Hill, 1972; McDonald, 1997). The benefits offered young mothers through these networks are quite varied, and they have proven to be most readily available to young mothers who reside with or live in close proximity to an extended family household (Hao \& Brinton, 1997; Hofferth, 1984; Hogan, Eggebeen, \& Clogg, 1993; Stevens, 1988).

Research also suggests that despite their substantial strengths, Black women-centered kin networks are not always up to the task. Kaplan's ethnographic study (1997), for example, revealed that Black teenage mothers often feel emotionally abandoned, even by their own mothers, and that emotional support to the young mothers is sometimes even withheld. A recent collection of statistically rigorous studies finds that extended kin support to young Black mothers is often ineffective or even nonexistent. Among them, two related studies find that some young, low-income African American mothers are likely to experience a lower quality relationship with their adult mothers when they coreside (Chase-Lansdale, Brooks-Gunn, \& Zamsky, 1994; Wakschlag, Chase-Lansdale, \& Brooks-Gunn, 1996). Other research finds no evidence that kin support has a positive impact on the maternal health or health practices of young Black mothers (Casper \& Hogan, 1990) and that, contrary to conventional wisdom, Black families 
are presently less likely than White families to be involved in giving intergenerational assistance (Roschelle, 1997). Fully one third of Black single mothers in one study are without an extended kin network from which to draw support of any kind (Hogan, Hao, \& Parish, 1990). Furthermore, close examination of two classic ethnographic studies of highly coordinated and effective Black maternal networks (Ladner, 1971; Stack, 1974) reveals several instances of the ways that these networks can thwart personal advancement.

Although intergenerational kin networks among Blacks have long been of interest to social scientists, they are now also directly relevant to current social welfare policy. The Personal Responsibility and Work Opportunity Reconciliation Act of 1996 (PRWORA), specifically TANF (Temporary Assistance for Needy Families, formerly AFDC), established far-reaching changes in the cash assistance available to disadvantaged teen mothers and set forth clear expectations for how young welfare-dependent mothers should be managed. In seeking to strengthen families, this law encourages job preparation by requiring mothers under the age of 18 to have completed high school or to be currently enrolled; it likewise encourages adult monitoring by requiring these mothers to live with a parent or adult family member (Mink, 1998). The enactment of these restrictions places great responsibility on adult kin for supervising teen mothers' transition from welfare to work, marriage, or both, and it assumes that kin women are willing and able to take on this challenge.

This study is an analysis of potential barriers to women-centered kin support for present-day urban Black teen mothers. It is motivated both by the mixed review of extended kin support offered in past research and by the need to clarify how the kin-support mandates under PRWORA may be actualized among urban Black teens. It moves beyond prior research by not only documenting that support deficiencies may exist, but that support may be lacking and even consciously withheld by midlife Black othermothers. Data are drawn from recent observations of Black midlife women who themselves became teen mothers more than 30 years ago (see Furstenberg, BrooksGunn, \& Morgan, 1987). In-depth interviews with these women shed light on their attitudes and perceptions about Black kinship systems and contemporary teen childbearing. These issues are considered in light of the significant demographic and social changes in urban Black families over time.

\section{THEORETICAL FRAMEWORK}

Scholarship on Black women's social history is laced with references to a "normative empathy" (McDonald, 1997) regulating African American mothering practices. The motivation to form and sustain kin support networks for young mothers is understood to be derived from a conjunction of empathy for other Black women who suffer or have suffered similar social disadvantages and of African American norms of solidarity, responsibility, and accountability. Historically, their unique race and gender status has strongly influenced how Black women define family and community and how they determine the types of strategies that are best suited to meet their needs, the needs of their families, and those of the race as a whole (Gilkes, 1989; Hine, 1990; Morgen \& Bookman, 1988; Naples, 1991, 1992).

The practice of normative empathy, however, is conditioned by the socioeconomic environment in which urban Black women live. Guided by a Wilsonian perspective, McDonald (1997) provided evidence that disadvantaged young Black mothers and potential midlife caregivers often become socially, culturally, and emotionally estranged from one another. As the material quality of life for young Black urban women has deteriorated, the quality and quantity of intergenerational kin support has also declined. Other authors also have conceded that informal maternal support traditions are not immune to problems of urban decline (Anderson, 1990; Baca Zinn, 1989; Collins, 1991; Ladner, 1986; Roschelle, 1997).

The practice of normative empathy also may be conditioned by both the fact and the fiction of Black teen welfare dependency as reported over the past 30 years. The Black rate of teenage pregnancy has doubled compared with that for Whites since the 1960s (Alan Guttmacher Institute, 1999; Kaplan, 1997). The majority of young Black mothers are either forced onto the welfare rolls or need to augment the public assistance their families already receive (Kaplan). Black teens constitute a minute proportion of mothers receiving public assistance-less than 1.2 percent (Mink, 1998)_but their reliance on welfare has helped fuel political debate over resolving the "immoral" economic dependency of unmarried Black mothers (Kaplan; Mandell, 1997; Mink, 1998; Mittelstadt, 1997). Over time, many African Americans have come to accept the "conservative" perspective on this matter (Kaplan), placing the blame for Black teen welfare dependency in part on the fail- 
ure of traditional kin systems to support the needs of their own.

Finally, the "age-condensed" family structure of intergenerational Black families (Burton, 1996, p. 20; Burton \& Dilworth-Anderson, 1991, p. 315), characterized by a consistent pattern of early childbearing across and within generations in families, presents yet another challenge to the practice of normative empathy. The resultant experience of being "kinscripted" (Stack \& Burton, 1994) prematurely into grandmothering, or a similar othermothering role via extended kin relations, has been common for many midlife women. Premature kinscription is more likely to occur among the economically disadvantaged, where early childbearing is more common (Butler, 1992). Each new generation of mothers finds itself pressured into accelerating the traditional maternal caregiving role, even as it may continue to need maternal caregiving of its own.

These cultural, economic, and demographic factors form the basis of the theoretical framework adopted to address the following research questions: How do Black midlife women characterize today's Black othermothering practices and the benefits they bring to teen mothers vis-à-vis their own early childbearing experience? If othermothering practices are characterized as waning, how do midlife Black women today account for this change? Answers to these questions may have serious implications for the success of PRWORAmandated kin support for today's Black teens.

\section{METHOD \\ Sample}

This study used qualitative data collected as part of an ongoing longitudinal study of teen childbearing begun in 1966. (For an overview of the Baltimore Study see Furstenberg, Brooks-Gunn, \& Morgan, 1987. A detailed Web site can be accessed at http://www.pop.upenn.edu/baltimore/). The Baltimore Study, under the direction of Frank F. Furstenberg, Jr., began as a formal survey of 399 disadvantaged urban women who became teen mothers (referred to as "G2s") in the late 1960s, their mothers ("G1s"), and their firstborn children ("G3s"). The G2s were all participants in one of the nation's first comprehensive health care programs for adolescent mothers, which operated out of a private hospital in the city. Eightyseven percent of this original sample were African American, and 82 percent were unmarried. The
Table 1. Demographic Characteristics of African American G2 Women, Baltimore Study (1966-1996)

\begin{tabular}{|c|c|c|c|}
\hline \multicolumn{3}{|c|}{ Survey Sample } & $\begin{array}{c}\text { Interview } \\
\text { Sample }\end{array}$ \\
\hline Year & 1966-1968 & 1995-1996 & 1996 \\
\hline Wave & Time 1 & Time 7 & Time 7 \\
\hline$n$ & 347 & 203 & 22 \\
\hline Mean age & 16.0 & 44.9 & 45.0 \\
\hline Never married & $88 \%$ & $17 \%$ & $27 \%$ \\
\hline $\begin{array}{l}<\text { High school diploma } \\
\text { or GED }\end{array}$ & $96 \%$ & $22 \%$ & $20 \%$ \\
\hline Receiving welfare & $34 \%$ & $9 \%$ & $14 \%$ \\
\hline White collar, managerial & $0 \%$ & $35 \%$ & $53 \%$ \\
\hline $\begin{array}{l}>\$ 31,000 / \text { year personal } \\
\text { income }\end{array}$ & $0 \%$ & $26 \%$ & $41 \%$ \\
\hline
\end{tabular}

educational and economic statuses of the sample were somewhat lower than for the general population of Blacks residing in Baltimore City at that time. The Baltimore Study, which contains seven waves of survey data, now spans more than 30 years and continues to involve 228 of the original G2 sample. Those no longer participating in the survey tended to marry, relocate outside the greater Baltimore metropolitan area, or both in the early years of the study.

A collection of intensive interviews serve as a supplement to the most recent survey of the full study sample (Time 7, 1995-1996). Our objective was to probe deeper into the experiences of the approximately 50 women who had been intensively interviewed prior to Time 7 or who were the mothers of previously interviewed G3 respondents. We determined that 32 of these $\mathrm{G} 2$ women had participated in the Time 7 formal survey, and experience taught us that consent for the intensive interviews was most likely to be given by these recent survey respondents. Of these, 22 responded favorably to our invitation to participate and were ultimately interviewed. All are African American.

Due to the nonrandom nature of this sampling procedure, the interviewees are slightly more educated than the Time 7 African American survey sample, somewhat more likely to have never married, and more likely to be employed in White collar professional and managerial positions and have incomes of more than $\$ 31,000$ (see Table 1). The average age of these former teen mothers was 45 years at the time of the interviews.

\section{Data Collection and Analysis}

The intensive interviewees were randomly assigned to the two authors, who conducted their 
sessions over a 3-month period. A common, relatively unstructured interview guide was designed to lead the $\mathrm{G} 2 \mathrm{~s}$ into discussions of their memories of their first pregnancies and births, their expectations at the time for help from kin and whether those expectations were met, mother-child communication about teen parenthood, social mobility and family networks throughout the life course, and life goals. All respondents were interviewed in their homes for 45 to 120 minutes. The interviews and accompanying oral field notes were tape-recorded and transcribed.

Guided by the theoretical framework and research questions adopted for this study, content analysis was performed to identify recurring themes among the respondents regarding their perceptions of intergenerational change in maternal support to young Black mothers. The life-history approach to data collection and analysis employed here is oriented toward the social-structural subjectivity of the respondent (see Bertaux \& Kohli, 1984). It takes as a given that all retrospection is social reconstruction; respondents continually update and reflect on accounts of their lives in accord with their current circumstances. Further, their self-understandings are not immune to influence from broader public understandings of various socially constructed "problems," such as teen childbearing, that impinge directly on their own experience. Thus, there is less concern with the validity of the retrospection than would be necessary in seeking to construct a historical sequence of life events. In as much as the accounts given by the respondents represent their points of view, which in turn may motivate their kin support practices, they constitute valid data for this research.

After having reviewed each piece of data extensively, the authors collaborated in devising the coding scheme that was used to organize the interview content; however, for consistency only one of the authors conducted the analysis. Coding of the intensive interview data was performed by hand and with the aid of computer software (NUD*IST). Coding was also performed with transcripts from prior intensive interviews with these same respondents; occasionally these prior interviews helped to fill in pertinent information about the G2 women's life histories.

"Teen mothers today," referred to frequently in these interviews by both the interviewers and respondents, are an important basis of comparison for the $\mathrm{G} 2$ women in considering intergenerational experiences of Black teen motherhood. These younger women are referred to as either "newgeneration" or "recent" teen mothers in this report. When speaking of new-generation teen mothers, G2 respondents referred in some cases their daughters (G3 women in their late 20s at the time of the interviews) who had been teen mothers and their daughters' peers. Twenty-seven percent of the G2 interviewees had daughters who had also been teen mothers; thus, more than a fourth have experienced new-generation teen motherhood first hand. In other cases, the reference was to the current generation of teen mothers.

\section{RESULTS}

This report begins with the G2 women's interpretations of their own teen childbearing experiences, then of new-generation teen motherhood. Because details of these findings are scattered throughout the interviews, it was often more efficient to paraphrase the women's collective voice. As a matter of reporting style, brief summaries of the findings, specific pieces of evidence, and some analytical comment are interwoven in each section. A more in-depth discussion and research conclusions are offered at the end of the article. The names of the respondents are changed to protect their individual identities.

\section{The Salience of Intergenerational Support}

The G2 women made numerous references to their early years of teen motherhood as a period of intense family cohesion. As Bessie put it, "Everyone was your family, your neighbor was your family, the pastor of the church was your family." This reported rallying by women kin around the G2 women frequently is cited as the primary agent by which most were able to advance educationally. Most often, the extended support received came in the form of shared housing, childcare assistance, moral support, and maternal guidance. When available, cash was supplied by multiple kin to help the mothers defray the costs of day care, food, and clothing.

The G2 women's recollections are confirmed by survey data collected in the years immediately following the birth of their first child (see Table 2). In their first year of motherhood, the G2 women relied heavily on their families for housing and child-care support. The results for our interview sample are substantively similar across all forms of assistance. Five years after the birth of their 
Table 2. Specific Kin Support to African American G2 Women, Survey and Interview Samples

\begin{tabular}{|c|c|c|c|c|}
\hline \multirow[b]{2}{*}{ Support Received } & \multicolumn{2}{|c|}{1 Year After First Birth } & \multicolumn{2}{|c|}{5 Years After First Birth } \\
\hline & Survey & Interview & Survey & Interview \\
\hline$n$ & 338 & 22 & 295 & 22 \\
\hline Share housing w/kin & $73 \%$ & $77 \%$ & $30 \%$ & $22 \%$ \\
\hline Living w/male partner & $21 \%$ & $14 \%$ & $30 \%$ & $45 \%$ \\
\hline Living alone & $1 \%$ & - & $21 \%$ & $23 \%$ \\
\hline \multicolumn{5}{|l|}{ Child care } \\
\hline G2 alone & $69 \%$ & $77 \%$ & $44 \%$ & $32 \%$ \\
\hline G2 and other & $21 \%$ & $18 \%$ & $10 \%$ & $5 \%$ \\
\hline Other caregiver alone & $1 \%$ & $5 \%$ & $40 \%$ & $45 \%$ \\
\hline \multicolumn{5}{|l|}{ Advice from kin } \\
\hline On feeding infant & $67 \%$ & $71 \%$ & - & - \\
\hline On infant's illness & $41 \%$ & $48 \%$ & - & - \\
\hline
\end{tabular}

Note: Percentages for shared housing and child care do not equal 100; omitted categories involve cases of infants in foster care or who were adopted.

first child, they continued to report both financial and nonmonetary assistance from their families. They received child care from kin even more extensively than they had just after the birth. Data from subsequent survey waves (not presented here) show that as the G2 women continued to age, levels of financial support from older kin dropped greatly, as expected. Continued kin support to $\mathrm{G} 2$ women at midlife may now be offered to help with the care of their grandchildren.

\section{Signs of Static in the Network}

Childrearing conflict was raised frequently by the G2 women as problematic for extended kin support they received. This conflict tended to revolve around who would fulfill the role of mother and even who would be entitled to be called "Mommy." This intergenerational role confusion sometimes led to open disputes, as Doreen noted:

It was like a pull between whose child was she. Was she my child or whose child was she ... It was a constant pull and a constant draining ... It became a point that I didn't feel like she was my child at all. I really didn't have any say-so over anything.

G2 women complain of their mothers contradicting the rules that they had set for their children's behavior or undermining their discipline by allowing their children to do things they themselves forbade.

It is somewhat peculiar that intra-network conflict did not appear to arise in any other form. The G2 women's reports lack reference to the constant, harsh scrutiny of teen girls' behavior by African
American community othermothers noted by other scholars, although there was some reference to the general reluctance of society to condone (or appear to condone) teen pregnancy in any way and to those women kin who worked to buffer them from insult. Kaplan's analysis of Black teen pregnancy (1997) and Anderson's study of an urban Black community (1990) suggest that during the 1950s and 1960s, G2 women would have found it difficult to escape the moralizing of "old women," a very important source of social control among African Americans. Furthermore, it was these same women who greatly influenced the mobilization of women kin in support (or nonsupport) of young mothers.

That G2 women's recollections of maternal support nevertheless tend toward the more pleasant is not surprising. In retrospect what seems to matter most to them now is that they survived young motherhood largely by accepting help from extended kin. That the first pregnancy could have been avoided or that women kin could have been less preachy about their condition is, for the most part, water under the bridge. Still, less romanticized versions of these tales are important to keep in mind as the $\mathrm{G} 2$ women relate their own experiences to those of teen mothers across the generations.

\section{New-Generation Teen Motherhood and Kin Support}

The G2 women's general consensus was that motherhood among new-generation teens is far more difficult than that experienced by former generations, and, more important, that new-gen- 
eration teen mothers lack Black extended kin support to buffer the effects of this hardship. Early childbearing today simply does not attract the attention of kin the way it once did, they explained. As Nikki noted, “I don't think they [teen mothers] got or [are] getting the support like I got it, you know ... I don't think the teen mothers get that kinda support from the family, you know, the extended family." Eighteen of the 22 women made direct claims to this effect or implied as much as they described what they believe are the economic and social circumstances by which both increased hardship and diminished kin support have come to be. In particular, governmental intervention and age-condensation among urban Black families, as well as the generational schism created by contemporary urban 'underclass' culture, were cited as having problematized attendance to teen motherhood within the African American community.

\section{Governmental Intervention}

The withholding of extended kin support is tied to what many $\mathrm{G} 2 \mathrm{~s}$ perceived as the proliferation of social services to young disadvantaged mothers since the 1960s. Welfare reform was not a subject addressed directly in the interviews with the G2 women, neither generically nor in reference to the specifics of the PRWORA, which was ratified a few months after our interviews were completed. Welfare dependence and its relationship to extended kin support, however, proved to be a salient concern.

Contrary to what they understand social welfare agencies to claim, the G2 women felt that such government-funded programs fail in their attempt to instill personal responsibility for childbearing. They generally believed that these programs operate in stark contrast to the kin support that once served as leverage for their personal advancement, not as an obstacle to it. The G2 women reported that they were never absolved by kin of their responsibility to build a stable socioeconomic future for themselves and their children, and they perceived that governmental programs inadvertently absolve young mothers to a certain degree. The G2 women also knew, however, that they could depend on the cultural wisdom and resourcefulness of kin women to guide them through the teen-mothering process, something governmental programs simply cannot replicate. In effect, the women suggest that governmental intervention and kin support systems are not only different but conflicting entities.
Despite whatever gains Black women have made as a result of reliance on social welfare, the G2 women felt that the cost of such assistance has been too great. Nikki explained that on the one hand,

Now [teen mothers] have everything they can possibly ask for to help them out. It all depends on how they use it. And we didn't have that many programs then and not only that, but they can [now] go directly to school, you know. When

I was coming up, we had to drop out.

On the other hand, however, the women felt that much of the maternal support activity today circumvents kin networks. Some suggested that in their day, successful mothering among teens was determined by how well the mother worked with kin to nurture her child and move up from her troubled circumstances, whereas teen mothers today measure success among themselves and by how well they can exploit governmental assistance. As Yvette noted:

This generation that's coming up now, [I] think the government has made it a little too easy for them ... I mean, they having a hard time, but my thing is that I think a lot of them are having these babies and they didn't know why they're having these babies and then they look for welfare to help them take care of these babies which isn't enough to help them. They don't wanna get out there and do anything as far as trying to help themselves.

As a consequence of overreliance on governmental assistance, the G2 women found that new-generation teen mothers lose out on most self-advancing benefits of extended Black kin support, namely in areas of education and childrearing.

The G2 women found that kin support to urban teen mothers in the past was predicated on the need to protect them from the stigma and socioeconomic constraints of early childbearing. Because teen pregnancy is now generally more accepted and supported materially by social welfare programs (broadly defined), they suggested that the function of kin support to legitimate and protect teen motherhood is no longer relevant. It is unclear, however, whether the lack of extended kin support the G2 women perceived is due to government interference or to the failure of extended kin to offer young mothers good familybased alternatives to welfare dependency and to recognize that most teen mothers do not desire the label "welfare mom"(Kaplan, 1997). 


\section{The Age-Condensation Factor}

There is evidence that at least two G2 women, poised to now self-indulge at midlife, have resisted the pressure to othermother in a significant way so that they can be free to finally pursue their personal life objectives. If not for themselves, they expressed strong sentiment about the need for other midlife women to now withhold much-needed resources for their own use. Field notes taken of Yvette's interview state that while she was sure she would have been very supportive had she had a daughter who conceived young, she is also certain that by midlife she would have made it clear that "this is my time" (emphasis hers). Bernice, whose sons fathered young, said that she speaks on behalf of many women like herself, as noted in the field notes taken during her interview:

She launched into a long discussion about the unwillingness of the women of her generation to take on the chore of raising their many grandchildren. She explained that "we" are still young and that "we" have a number of things "we" want to accomplish, and "we" don't want to be home taking care of a bunch of babies.

The women of this study appeared weary, in various degrees, from their lives having been so concentrated on resolving classic problems of teen motherhood, and later resolving problems for their adolescent children, their aging parents, and other kin and fictive kin to whom they were obligated. Grace, who now shares a home with her female companion and the six school-age sons they brought together as family, admitted that she looks forward to those times when people take the children away for the weekend. Anxious to move beyond the mothering phase of life, Grace sought to replenish her economic reserves and devote her energies primarily to enjoying time with her companion.

The weariness expressed by the G2 interviewees may indeed apply to a good proportion of the African American G2 women surveyed. Now 30 years after the birth of their first child, $77 \%$ of the G2 women are grandmothers, and $18 \%$ live with grandchildren. The $\mathrm{G} 2$ women continue to assume a large burden of responsibility for these grandchildren, with $62 \%$ sharing at least partial responsibility for them. Consequently, the very segment of the Black community traditionally portrayed as an effective, empathic resource for disadvantaged young mothers is likely to retreat from its cultural responsibility in the present day. Black midlife women, many of whom are “ 'out of sync' with generational position" by virtue of their early childbearing, the early childbearing by others in the kin network, or both (Burton, 1996, p. 201), are perceived as contributing significantly to the dearth of informal maternal support.

Despite the age-condensation of extended kin networks and the myriad socioenvironmental factors that they claimed have undermined relationships with kin, several G2 women made a point of offering examples of how their own committed practice of normative empathy is a mainstay among early childbearing kin. Violet, for instance, shared a detailed account of how she guided her daughter through her early years of teen motherhood by lovingly "demanding" that her daughter complete high school and not delegate her parenting responsibilities to anyone else. Likewise, Sharon proudly described her style of othermothering:

I gotta lot to give [teen mothers], and kids have
been following me for years. I mean, even when
like Delcia (her daughter) was 12 I started a teen
talk group in our area and [my] family insisted
that I move them out of the house because I start-
ed taking people in the house, you know, coun-
seling, giving them whatever they needed ...
teen mothers are my concentration.

\section{A Menacing Urban Teen Culture}

The G2 women found that the changing landscape of urban life seems to have so differentiated teen childbearing experiences over the generations as to make the practice of normative empathy by midlife kin women rare. They explained that many African American othermothers are dismayed by a sense of powerlessness over the lives of streetwise young urban women and that this has led to a retreat from their caregiving role. As Sharon put it, "they're giving up in mass quantities, especially in neighborhoods where there are .. . less chances for moving up financially." For new-generation teens, childbearing is structured by a "new" urban context replete with distractions from the traditional, moral order of Black motherhood.

Among other things, new-generation teen mothers and their peers were portrayed as more contemporarily streetwise about sex and illicit drugs than are their midlife kin. As Stella noted, "When [my sisters and I] were coming up, sure we snuck and smoked cigarettes and drank beer or something like that, but now the kids are doing everything, you know. It's just no limit to what 
they do no more." Urban young women are portrayed as intoxicated and lured by a materially profitable and sexually fulfilling life "sold" by sex and illicit drug power brokers, often teenagers themselves. As Patsy noted, 'I'll put it this way ... It's like the [teen's] child doesn't exist. The money's on them. I mean, they put it on drugs and jewelry, the hair. This is our teens today."

By most G2 accounts, "peer pressure" to conceive young and to make peers, rather than child and kin, the center of one's life is unique to today's inner city. Extended kin, frustrated and afraid for their own lives, are often forced to withhold the maternal support they would otherwise lend. (See Anderson, 1990, for a detailed discussion of "streetwisdom," sex codes, and peer authority among urban youth.)

Although the G2 women blamed gangster life and gangster mentality in large part for leading young mothers and prospective young mothers from the protection of family, the G2 women seemed equally willing to blame adult kin for retreating too far out of fear or frustration. Newgeneration teen mothers were described as having to "fend for themselves" (Flora), as having "no support [from adult kin] whatsoever" (Yvette). The images painted are of adult mothers, particularly, who are consistently absent from the dayto-day activities of their early childbearing daughters, failing to provide and protect then from urban teen culture. By not experiencing early childbearing under the watchful, loving care of othermothers, the G2 women argued that new-generation teen mothers fail to mother their own children properly.

\section{DisCUSSION AND CONCLUSION}

Not all new-generation urban Black teen mothers will be directly affected by the recent ratification of federal welfare reform policies; the vast majority do not require institutional support for economic stability. These mothers will, however, be disproportionately represented among those who will soon be faced with finding alternative resources for support. The TANF coresidency mandate assumes that African American family members are available in abundance to take over much of the responsibility-or in the spirit of these reforms, reclaim the responsibility - of mainstreaming their young kin (namely, the unmarried poor), economically and morally. Decades of past research extolling the unique support infrastructure of women-centered African American kin net- works to some extent serve to validate such an assumption (Roschelle, 1997), but the findings from the study reported here, as well as those upon which it builds, caution us to reevaluate it.

Certainly we cannot ignore the general tendency of older generations to differentiate themselves and their experiences from younger ones and to romanticize the past, believing that "things were different then." The G2 women's potentially romanticized reconstructions of their past make the basis of comparison to teen mothers across the generations somewhat tenuous. Yet neither can we ignore that the former Black teen mothers we interviewed for this study lamented what they describe as a dramatically diminished presence of Black extended kin in the lives of urban teen mothers, perhaps even more so among the welfare-dependent. The qualitatively different experiences the G2 women perceived across generations of young Black mothers call into question the ease with which intergenerational empathy and solidarity are evoked even among those similarly disadvantaged by early childbearing.

The respondents' indictment of proliferating governmental assistance programs for dislocating Black teen mothers from traditional kin networks speaks to elements of both conservative and liberal political camps. For more than a decade, there has been fierce debate among scholars over what some have characterized as the detrimental effects of the Great Society effort on behalf of inner-city populations (Harris, 1997; Moffitt, 1998). Conservatives have argued that through the establishment of massive federal support programs, the nation made welfare dependency an attractive choice, whereas liberals have argued that the swelling of welfare enrollment occurred out of economic necessity (Venkatesh, 1994). The conservative voice of the G2 women reasons that these programs require very little personal initiative from the young mother. Their liberal leaning is less obvious, but there are signs the women recognize that severely reduced, meaningful opportunities for social mobility and marriage in the inner city have driven young mothers to maximize their reliance on welfare.

One of the most intriguing findings of this research is the seemingly contradictory position these contemporary Black midlife women took on maternal caregiving. Many of the respondents are quick to credit significant elder women kin and the receipt of informal maternal support to their having beaten the odds as teen mothers some 30 years ago. Yet they also were quick to judge the 
current state of extended kin support by Black midlife women to be vacuous for the most part, net of any effect of urban decline and welfare dependency. They were curiously embittered by and sympathetic with midlife women who have retreated from maternal caregiving to preserve their own lives. In those cases where the G2's offspring bore children young as well, her grandparenting work load potentially intensifies. In response, many new-generation teen mothers may find themselves, in effect, turned over to other nonfamilial sources of support less satisfying for them and for the Black urban community at large.

Feeling weary from years of managing children and grandchildren is not unique to those who are Black. Cherlin \& Furstenberg (1986) observed similar views among midlife and elder persons of various racial and ethnic backgrounds, and they concluded that "given the central place of personal autonomy in American culture and the improved material circumstances of older people, the shift among grandparents toward greater independence seems inexorable" (p. 189). However, as Hunter \& Taylor (1998) explained, the desire for personal autonomy may be stronger for those who experienced early childbearing, single parenthood, economic hardship, or a combination thereof. Any one of these factors tend to place inordinate pressure on midlife women to lend support; multiple factors experienced simultaneously or successively throughout the life course are sure to wear them down.

Granted, several of the G2 women provided convincing personal accounts of caregiving on their part that defy this characterization of midlife behavior under age-condensation, and the survey data suggest more caregiving is taking place among midlife women than the interviewees know or are willing to admit. But what of their general assertion that kin support is lacking? The women of this study made great effort to dissociate themselves from those who have retreated from the traditional work of Black women kin. The classic problem with dissociation, however, is that it usually leads to the blurring of lines between "them" and "me." Some of these G2 women and those on behalf of whom they speak are very likely among "those" absent, inattentive, and ineffective Black extended kin.

The G2 women's explications on the growing social isolation of Black urban youth are consistent in many ways with past theorizing and research (Anderson, 1990; Collins, 1991; Kasarda, 1989; Wilson, 1987). The extensive sociological literature describing the causes and effects of urban dislocation gives credence to the suggestion that the withholding of intergenerational support to young mothers is largely motivated by frustrations with an uncooperative, menacing teen culture. The respondents perceive that many midlife women have retreated from their roles as othermothers, unable to compete with a new urban youth culture that prides itself on bearing children young while maintaining a street life fraught with distractions from maternal responsibility. In the context of these interviews, the women neglected to consider whether the withholding of extended kin support to young mothers is largely to blame for the very thing they claim drives that support away. It is also quite possible that much of what the G2 women claim to witness as urban fearinduced neglect of young kin may actually be a withholding of support for reasons endemic to the circumstances of caregivers' lives rather than those of young mothers. That is, parental absenteeism may have led young mothers to seek support from peers where it is most likely to have been given.

In sum, this research offers a more comprehensive understanding of what a series of recent studies has revealed: Intergenerational support to contemporary young African American mothers may be neither as abundant nor as ubiquitous today as past theorizing on the Black family intimated. It remains unclear whether extended women kin, traditionally the center of such activity, are less likely to practice normative empathy today than in the past or whether past estimates of support receipt are exaggerated. To address these issues, future research is needed to adequately trace the prevalence of intergenerational support among African Americans over time. Furthermore, studies that examine the actual behavior of Black families in response to the recent welfare reforms will be essential to linking pre-reform attitudes and perceptions to post-reform outcomes for teen mothers. Ideally, such analyses would be based on less restrictive data than is used here (e.g. a geographically bounded sample of early childbearers). Until then, we should be somewhat reserved today in our expectations for welfare eligibility support from urban midlife women; they may be hesitant to invest their resources in light of what can often feel like insurmountable structural obstacles to effective othermothering.

This study suggests that moving economically disadvantaged young mothers from welfare rolls to employment rosters, the course social policy 
and federal law are now taking, is an extremely complex matter for Black families. Where kin support for young Black mothers is available, the current welfare reform is likely to be seen as an opportunity for Black midlife women to help restore familial authority through their traditional othermothering practices. The intergenerational housing arrangement will provide for closer oversight of adolescent childrearing and for the encouragement of legitimate means by which young Black mothers establish economic independence and mobility. On the other hand, where Black women kin support is absent or sorely lacking, welfare reform may leave some young mothers with no support of any kind. Thus, even as the G2 women express a good deal of disdain for the pre-PRWORA welfare system and its undermining of teen mothers' well-being, they are likely to be unprepared when the realities of the recent reforms become manifest in the lives of their young kin. Better we anticipate what may be the reluctance by some Black families to help meet the needs of poor Black teen mothers than to assume that family-anchored welfare-to-work programs will be unquestionably successful.

\section{NOTE}

A special debt is owed to Frank F. Furstenberg, Jr., Andrew Cherlin, Lingxin Hao, and Doris Entwisle for their comments on earlier drafts of this article.

\section{REFERENCES}

Anderson, E. (1990). Streetwise: Race, class, and change in an urban community. Chicago: University of Chicago Press.

Alan Guttmacher Institute. (1999). Teenage pregnancy: Overall trends and state-by-state information. Retrieved October 1, 2000, from the World Wide Web: http://www.agi-usa.org/pubs/ teen_preg_stats.html

Baca Zinn, M. (1990). Family, race, and poverty in the eighties. In M. R. Malso, E. Mudimbe-Boyi, J. F, O'Barr, \& M. Wyer (Eds.), Black women in America (pp. 245-263). Chicago: University of Chicago Press.

Ball, R. E., Warheit, G. J., Vandiver, J. S., \& Holzer, C. E., III. (1980). Friendship networks: More supportive of low-income Black women. Ethnicity, 7, 70-77

Bertaux, D., \& Kohli, M. (1984). The life story approach: A continental view. Annual Review of Sociology, 10, 215-37.

Butler, A. (1992). The changing economic consequences of teenage childbearing. Social Service Review, 66, $1-31$.

Burton, L. M. (1996). Age norms, the timing of family role transitions, and intergenerational caregiving among aging African American women. Gerontologist, 36, 199-208.

Burton, L. M., \&, Dilworth-Anderson, P. (1991). The intergenerational family roles of aged Black Americans. Marriage and Family Review, 16, 311-330.

Casper, L. M., \& Hogan, D. P. (1990). Family networks in prenatal and postnatal health. Social Biology, 37, 84-101.

Chase-Lansdale, P. L., Brooks-Gunn, J., \& Zamsky, E. S. (1994). Young African American multigenerational families in poverty: Quality of mothering and grandmothering. Child Development, 65, 373-393.

Cherlin, A. J., \& Furstenberg, F. F., Jr. (1986). The new American grandparent: A place in the family, a life apart. New York: Basic Books.

Collins, P. H. (1991). Black feminist thought: Knowledge, consciousness, and the politics of empowerment. New York: Routledge.

Furstenberg, F. F., Jr., Brooks-Gunn, J., \& Morgan, S. P. (1987). Adolescent Mothers in later life. New York: Cambridge University Press.

Gilkes, C. T. (1989). Dual heroisms and double burdens: Interpreting Afro-America womens's experiences and history. Feminist Studies, 15, 573-590.

Hao, L., \& Brinton, M. C. (1997). Productive activities and support systems of single mothers. American Journal of Sociology, 102, 1305-1344.

Harris, K. M. (1997). Teen mothers and the revolving welfare door. Philadelphia: Temple University Press.

Hill, R. B. (1972). The strength of Black families. New York: Emerson Hall.

Hine, D. C. (1990). "We specialize in the wholly impossible": The philanthropic work of Black women. In K. D. McCarthy (Ed.), Lady bountiful revisited: Women, philanthropy, and power (pp. 70-93). New Brunswick, NJ: Rutgers University Press.

Hofferth, S. (1984). Kin networks, race, and family structure. Journal of Marriage and the Family, 46, 791-806.

Hogan, D. P., Eggebeen, D. J., \& Clogg, C. C. (1993). The structure of intergenerational exchanges in American families. American Journal of Sociology, 98, 1428-1458.

Hogan, D. P., Hao, L., \&, Parish, W. L. (1990). Race, kin networks, and assistance to mother-headed families. Social Forces, 68, 797-812.

Hunter, A. G., \& Taylor, R. J. (1998). Grandparenthood in African American families. In M. E. Szinovacz (Ed.), Handbook of grandparenthood (pp. 70-86). Westport, CT: London.

James, S. M. (1993). Mothering: A possible Black feminist link to social transformations. In S. James \& A. Busia (Eds.), Theorizing Black feminisms: The visionary pragmatisms of Black women (pp. 44-54). London: Routledge.

Kaplan, E. B. (1997). Not our kind of girl: unraveling the myths of Black teenage motherhood. Berkeley: University of California Press.

Kasarda, J. (1989). Urban industrial transition and the underclass. Annuals of the American Academy of Political and Social Science, 501, 26-47.

Ladner, J. (1971). Tomorrow's tomorrow: The Black woman. Garden City, NY: Anchor Books.

Ladner, J. (1986). Black women face the 21 st century: Major issues and problems. The Black Scholar, 17, 12-19.

Mandell, B. R. (1997). Poor women and children need welfare. In C. P. Cozic (Ed.), Welfare reform (pp. 1026). San Diego, CA: Greenhaven Press. 
McDonald, K. B. (1997). Black activist mothering: A historical intersection of race, gender, and class. Gender \& Society, 11, 773-795.

Mink, G. (1998). Welfare's end. Ithaca, NY: Cornell University Press.

Mittelstadt, J. (1997). Educating "our girls" and "welfare mothers": Discussions of education policy for pregnant and parenting adolescents in federal hearings, 1975-1995. Journal of Family History, 22, 326353.

Moffitt, R. A. (1998). Introduction. In R. A. Moffitt (Ed.), Welfare, the family, and reproductive behavior: Research perspectives (pp. 1-8). Washington, DC: National Academy Press.

Morgen, S., \& Bookman, A. (1988). Rethinking women and politics: An introductory essay. In A. Bookmen \& S. Morgen (Eds.), Women and the politics of empowerment (pp. 3-29). Philadelphia: Temple University Press.

Naples, N. (1991). "Just what needed to be done": The political practice of women community workers in low-income neighborhoods. Gender \& Society, 5 478-494.

Naples, N. 1992. Activist mothering: Cross-generational continuity in the community work of women from low-income neighborhoods. Gender \& Society, 6 , 441-463.
Roschelle, A. R. (1997). No more kin: Exploring race, class, and gender in family networks. Thousand Oaks, CA: Sage.

Stack, C. (1974). All our kin: Strategies for survival in a Black community. New York: Harper \& Row.

Stack, C., \& Burton, L. M. (1994). Kinscripts: Reflections on the family, generation and culture. In E. N. Glenn, G. Change, \& L. R. Forcey (Eds.), Mothering: Ideology, experience, and agency (pp. 33-44). New York: Routledge.

Stevens, J. H., Jr. (1984). Black grandmothers' and Black adolescent knowledge about parenting. Developmental Psychology, 20, 1017-1025.

Stevens, J. H. (1988). Social support, locus of control, and parenting in three low-income groups of mothers: Black teenagers, Black adults, and White adults. Child Development, 59, 635-642.

Venkatesh, S. A. (1994). Getting ahead: Social mobility among the urban poor. Sociological Perspectives, 37 , 157-182.

Wakschlag, L. S., Chase-Lansdale, P. L., \& BrooksGunn, J. (1996). Not just "ghosts in the nursery": Contemporaneous intergenerational relationships and parenting in young African American families. Child Development, 67, 2131-2147.

Wilson, W. J. (1987). The truly disadvantaged: The inner city, the underclass, and public policy. Chicago: University of Chicago Press. 